\title{
AS SÚMULAS VINCULANTES NO BRASIL E A NECESSIDADE DE LIMITES AO ATIVISMO JUDICIAL
}

THE BINDING PRECEDENTHS IN BRAZIL AND THE NEED FOR LIMITS ON JUDICIAL

\author{
ACTIVISM
}

Alexandre de Moraes*

\begin{abstract}
Resumo:
O Autor aborda que, a partir do fortalecimento da jurisdição constitucional, Constituição/1988, novas técnicas interpretativas serão permitidas, no intuito de ampliar a atuação jurisdicional em assuntos tradicionalmente de alçada dos Poderes Legislativo e Executivo.

Palavras-chave: Supremo Tribunal Federal. Emenda Constitucional n. 45 de 2004. Súmulas vinculantes.
\end{abstract}

\begin{abstract}
:
The author discusses that, from the strengthening of constitutional jurisdiction, Constituição/1988, new interpretive techniques will be allowed in order to expand operations in jurisdictional matters traditionally the purview of the Legislative and Executive.
\end{abstract}

Keywords: Supreme Court. Constitutional Amendment. 45, 2004. Binding precedents.

1. Introdução

No Brasil, a partir do fortalecimento da Jurisdição Constitucional pela Constituição de 1988, principalmente pelos complexos mecanismos de controle de constitucionalidade e pelo vigor dos efeitos de suas decisões, em especial os efeitos erga omnes e vinculantes, e das "Súmulas Vinculantes", somados à inércia dos Poderes Políticos em efetivar totalmente as normas constitucionais, vem permitindo que novas técnicas interpretativas ampliem a atuação jurisdicional em assuntos tradicionalmente de alçadas dos Poderes Legislativo e Executivo.

A possibilidade do Supremo Tribunal Federal em conceder interpretações conforme à Constituição, declarações de nulidade sem redução de texto, e, ainda, mais recentemente, à partir da edição da Emenda Constitucional n. 45/04, a autorização

\footnotetext{
Alexandre de Moraes é Doutor e Livre-docente em Direito Constitucional pela Universidade de São Paulo. Professor-associado da USP e Titular da Universidade Mackenzie. Advogado e Consultor Jurídico. Foi Promotor de Justiça em São Paulo (1991-2002), Secretário de Estado da Justiça em São Paulo (2002-2005), Membro do Conselho Nacional de Justiça (biênio 2005-2007) e Secretários de Transportes e Serviços em São Paulo (2007-2010). alexandre@alexandredemoraes.com.
} 
constitucional para editar, de ofício, Súmulas Vinculantes não só no tocante à vigência e eficácia do ordenamento jurídico, mas também em relação à sua interpretação, acabaram por permitir, não raras vezes, a transformação da Corte em verdadeiro legislador positivo, completando e especificando princípios e conceitos indeterminados do texto constitucional; ou ainda, moldando sua interpretação com elevado grau de subjetivismo.

Essa realidade torna cada vez mais necessária a reestruturação da tradicional teoria da tripartição de Poderes e, principalmente, a compatibilização e harmonização das duas "grandes qualidades" existentes no moderno Estado Constitucional: Estado de direito e Estado Democrático.

2. Estado constitucional: estado de direito e Estado democrático

As lições de Pontes de Miranda apontam o surgimento do Estado, tal qual conhecemos hoje, somente no século XV, ${ }^{1}$ enquanto Jorge Miranda aponta o século XVI como o marco inicial do Estado, ${ }^{2}$ diferenciando-os das organizações anteriores, como lembra Pablo Lucas Verdú. ${ }^{3}$

São várias as teorias que justificam sua existência, explicando-o pela legitimidade da criação do mais forte (teoria do poder de Hobbes), dos laços jurídico-sociológicos (Pacto social de Rousseau e Kant), da vontade divina (Santo Agostinho), ou ainda, da necessidade moral (Platão, Aristóteles, e mais recentemente, Hegel). Igualmente, outras tantas teorias pretendem justificar os fins do Estado, apontando-o como necessário à conservação das instituições (Stahl), à realização e aperfeiçoamento moral (Hegel), à realização do direito (Locke, Kant), à criação e asseguração da felicidade (Cristiano Wolff e Bentham), ou ainda, como apontam a teoria do materialismo histórico estatalista, para a realização da igualdade econômica. Kelsen, dentro do estrito formalismo, justifica o Estado como o "fim em si-mesmo".

As teorias são complementares, pois o Estado sempre almeja fins, ainda que difusos, definíveis e mutáveis e para o pensamento político-constitucional trata-se de uma categoria estruturante. ${ }^{4}$

Nesse contexto histórico, o constitucionalismo escrito surge com o Estado, também com a função de racionalização e humanização, trazendo consigo a necessidade da proclamação de declarações de direitos. ${ }^{5}$

MIRANDA, Francisco Cavalcanti Pontes de. Comentários à constituição de 1946. v. 1, p. 39.

MIRANDA, Jorge. Manual de direito constitucional. t. 3, p. 20 ss.

VERDÚ, Pablo Lucas. A luta pelo estado de direito. Trad. Agassiz Almeida Filho. Rio de Janeiro: Forense, 2007. p. 23.

4 Como tivemos oportunidade de salientar em nosso MORAES, Alexandre de. Direito constitucional. 26. ed. São Paulo: Atlas, 2010. p. 02 ss.

5 Surgem as novas declarações de Direitos, com a Declaração de Direitos da Virgínia, de 16 de junho de 1776 , 
O Estado de Direito é consagrado com o constitucionalismo liberal do século XIX, se destacando a Constituição de Cádis, de 19-3-1812, a $1^{\text {a }}$ Constituição Portuguesa, de 23-9-1822, a 1* Constituição Brasileira, de 25-3-1824 e a Constituição Belga, de 7-2-1831; seguidos pela Declaração de Direitos da Constituição Francesa de 4-11-1848, texto precursor do Século XX, por consagrar princípios de liberdade, igualdade e fraternidade e ampla proteção ao cidadão.

A necessidade de racionalização e humanização faz com que os textos escritos exijam que todo o âmbito estatal esteja presidido por normas jurídicas, que o poder estatal e a atividade por ele desenvolvida se ajustem ao que é determinado pelas previsões legais, ou seja, a submissão de todos ao Estado de Direito e a necessidade de edificação de sua construção jurídica, com salientado por Maurice Hariou e Leon Duguit. $^{6}$

Igualmente, no século XIX, o manifesto comunista de Karl Marx passou a embasar teoricamente o movimento dos trabalhadores, e, juntamente, com os reflexos do cartismo na Inglaterra e à Comuna de 1871, na França, passam a minar as até então sólidas bases do Estado Liberal.

A partir da Constituição de Weimar (1919), que serviu de modelo para inúmeras outras constituições do primeiro pós-guerra, e apesar de ser tecnicamente uma constituição consagradora de uma democracia liberal - trouxe a crescente constitucionalização dos direitos sociais, elevados à categoria de princípios constitucionais protegidos pelas garantias do Estado de Direito.

O Estado de Direito, já com a constitucionalização dos direitos sociais e econômicos, no período anterior à 2 Grande Guerra foi criticado por autores nacionalsocialistas (Reinhard Hohn) e definido como a antítese do Estado bolchevique (Koellreutter), mas também já foi denominado Estado Ético, no constitucionalismo italiano, imediatamente pós-guerra (1947 - Felice Battaglia).

A evolução do Estado consagrou a necessidade da fórmula Estado de Direito, que, conforme salientado por Pablo Lucas Verdú, "ainda exerce particular fascinação sobre os juristas". Essa fórmula aponta a necessidade do Direito ser respeitoso com as liberdades individuais tuteladas pelo Poder Público.

Essa evolução foi acompanhada pela consagração de novas formas de exercício da democracia representativa, em especial, com a tendência de universalização do voto e constante legitimação dos detentores do Poder, fazendo

a Declaração de Independência dos Estados Unidos da América, de 4 de julho de 1776, e a Constituição dos Estados Unidos, de 17 de setembro de 1787, com suas dez primeiras emendas aprovadas em 25 de setembro de 1789 e ratificadas em 15 de dezembro de 1791. Conferir importantíssima coletânea do Professor Jorge Miranda: (MIRANDA, Jorge. Textos históricos do direito constitucional. 2. ed. Lisboa: Imprensa Nacional, 1990.).

6 DUGUIT, Leon. Fundamentos do direito. São Paulo: Íconce, 1996. p. 9. 
surgir a ideia de Estado Democrático, pautado por regras constitucionais. A importância dessa evolução é ressaltada tanto por Jorge Miranda, ${ }^{7}$ quanto por Canotilho. ${ }^{8}$

O Estado Constitucional configura-se, portanto, como uma das grandes conquistas da humanidade, que, para ser um verdadeiro Estado de qualidades no constitucionalismo moderno deve ser um Estado democrático de direito.

Dessa forma, são duas as "grandes qualidades" do Estado Constitucional: Estado de direito e Estado democrático.

O Estado de Direito caracteriza-se por apresentar as seguintes premissas: (1) primazia da lei, (2) sistema hierárquico de normas que preserva a segurança jurídica e que se concretiza na diferente natureza das distintas normas e em seu correspondente âmbito de validade; (3) observância obrigatória da legalidade pela administração pública; (4) separação de poderes como garantia da liberdade ou controle de possíveis abusos; (5) reconhecimento da personalidade jurídica do Estado, que mantém relações jurídicas com os cidadãos; (6) reconhecimento e garantia dos direitos fundamentais incorporados à ordem constitucional; (7) em alguns casos, a existência de controle de constitucionalidade das leis como garantia ante o despotismo do Legislativo.

Assim, existirá o Estado de Direito onde houver a supremacia da legalidade, ou para o direito inglês a The Rule of Law, para o direito francês o État Legal, para o direito alemão o Rechtsstaat, ou ainda, a always under law do direito norte-americano.

A interpretação da The Rule of Law, apesar de sua evolução e variações históricas, pode ser apontada em suas quatro dimensões: (1) observância do devido processo legal (Magna Charta de 1215); (2) predominância das leis e dos costumes do "país" perante a discricionariedade do poder real; (3) sujeição de todos os atos do executivo à soberania do Parlamento; (4) igualdade de acesso aos tribunais para defesa dos direitos consagrados.

L'État legal consagrou-se no constitucionalismo francês com a construção de hierarquia na ordem jurídica, prevendo no vértice da pirâmide as declarações de direitos e, posteriormente, o texto constitucional.

O Rechtsstaat, surgido no início do século XIX na Alemanha, pretendeu substituir a ideia de Estado de Polícia, onde tudo é regulamento e controlado pelo Estado, pela ideia de Estado de Direito, no sentido de proteção a ordem e segurança pública, porém com liberdade ao particular nos campos econômicos e sociais, e, garantindo-se um amplo modelo protetivo de jurisdição ordinária.

\footnotetext{
7 MIRANDA, Jorge. Manual de direito constitucional. 4. ed. Coimbra: Coimbra Editora, 1990. t. 1, p. 13-14.

8 CANOTILHO, J. J. Gomes. Direito constitucional e teoria da Constituição. Coimbra: Almedina, 2003. p. 87.
} 
Nos Estados Unidos da América, a consagração do Estado de Direito deu-se com a aplicação prática da ampla revisão judicial, no célebre caso Marbury v. Madison (1803), quando a Corte Suprema, conduzida pelo Juiz-Presidente Marshal, proclamou a superioridade das normas constitucionais sobre todo o restante do ordenamento jurídico, inclusive sobre os atos do Poder Legislativo, corroborando, dessa forma, as afirmações anteriores de Hamilton, que apontou sobre o tema: "Esta conclusão não supõe de modo algum uma superioridade do poder judiciário sobre o legislativo. Supõe apenas que o poder do povo é superior a ambos, e que, quando a vontade do legislativo, expressa em suas leis, entre em oposição com a do povo, expressa na Constituição, os juízes devem ser governados por esta última e não pelas primeiras. Devem regular suas decisões pelas leis fundamentais, não pelas que não são fundamentais." (The federalist papers LXXVIII). ${ }^{9}$

Por outro lado, e de maneira complementar, a defesa de um Estado Democrático pretende, precipuamente, afastar a tendência humana ao autoritarismo e à concentração de poder. Como ensina Giuseppe de Vergottini, o estado autoritário, em breve síntese, caracteriza-se pela concentração no exercício do poder, prescindindo do consenso dos governados e repudiando o sistema de organização liberal, principalmente a separação das funções do poder e as garantias individuais. ${ }^{10}$ Maurice Duverger, ao analisar a complexidade da conceituação da Democracia, aponta "a definição mais simples e mais realista de Democracia: regime em que os governantes são escolhidos pelos governados; por intermédio de eleições honestas e livres". ${ }^{11}$

O Estado Democrático de Direito, caracterizador do Estado Constitucional, significa que o Estado se reger por normas democráticas, com eleições livres, periódicas e pelo povo, bem como o respeito das autoridades públicas aos direitos e garantias fundamentais, é proclamado, por exemplo, no caput do art. 1 da Constituição da República Federativa do Brasil, que adotou, igualmente, em seu parágrafo único, o denominado princípio democrático ao afirmar que "todo o poder emana do povo, que o exerce por meio de representantes eleitos ou diretamente, nos termos desta Constituição", para mais adiante, em seu art. 14, proclamar que "a soberania popular será exercida pelo sufrágio universal e pelo voto direto e secreto, com valor igual para todos, e, nos termos da lei, mediante: I - plebiscito; II - referendo; III - iniciativa popular".

\footnotetext{
Conferir amplo estudo sobre Jurisdição Constitucional em nosso: MORAES, Alexandre de. Jurisdição constitucional e tribunais constitucionais. 2. ed. São Paulo: Atlas, 2002.

10 VERGOTTINI, Giuseppe de. Diritto costituzionale comparato. Pádua: Cedam, 1981. p. 589.

11 DUVERGER, Maurice. Os partidos políticos. Rio de Janeiro: Zahar, 1970. p. 387.
} 
Assim, o princípio democrático exprime fundamentalmente a exigência da integral participação de todos e de cada uma das pessoas na vida política do país, a fim de garantir o respeito à soberania popular. ${ }^{12}$

O Estado Constitucional, portanto, é mais do que o Estado de Direito, é também o Estado Democrático, introduzido no constitucionalismo como garantia de legitimação e limitação do poder.

3. Reforma do Poder Judiciário E adoção das Súmulas Vinculantes no Brasil (EC n. 45/04)

A instituição da súmula vinculante, pela EC n. 45/04, corresponde à tentativa de adaptação do modelo da common law (stare decisis) para nosso sistema romano-germânico (civil law); porém, é importante relembrar que essa ideia já fora adotada no Império, quando, em 1876, o Supremo Tribunal de Justiça passou a ter a possibilidade de editar assentos com força de lei, em relação à "inteligência das leis civis, comerciais e criminais, quando na execução delas ocorrerem dúvidas manifestadas no julgamento divergentes do mesmo tribunal, das Relações e dos Juízes", nos termos do art. $2^{\circ}$, do Decreto n. 6.142, de 10-3-1876, sem porém que tivesse sido utilizado até a proclamação da República.

As súmulas vinculantes surgem a partir da necessidade de reforço à ideia de uma única interpretação jurídica para o mesmo texto constitucional ou legal, de maneira a assegurar-se a segurança jurídica e o princípio da igualdade, pois os órgãos do Poder Judiciário não devem aplicar as leis e atos normativos aos casos concretos de forma a criar ou aumentar desigualdades arbitrárias, devendo, pois, utilizar-se de todos os mecanismos constitucionais no sentido de conceder às normas jurídicas uma interpretação única e igualitária.

Não foi outra a intenção do legislador constituinte ao estabelecer como competência do Supremo Tribunal Federal o julgamento dos recursos extraordinários (uniformização na interpretação da Constituição Federal) e competência ao Superior Tribunal de Justiça para o julgamento dos recursos especiais (uniformização na interpretação da legislação federal).

Esse modelo, porém, não se mostrou célere e suficiente para impedir desigualdades perpetradas por diferentes interpretações judiciais da mesma norma, buscando o legislador constituinte derivado, no modelo anglo-saxônico, o stare decisis, da expressão stare decisis et quieta non movere (mantenha-se a decisão e não

12 Cf. em relação ao estudo da necessidade do equilíbrio democrático perante o Presidencialismo, nossa obra: MORAES, Alexandre de. Presidencialismo. São Paulo: Atlas, 2004. Conferir, ainda: CANOTILHO, J. J. Gomes; MOREIRA, Vital. Fundamentos da Constituição. Coimbra: Coimbra Editora, 1991. p. 195; CAETANO, Marcello. Direito constitucional. 2. ed. Rio de Janeiro: Forense, 1987. v. 1, p. 169. 
se perturbe o que foi decidido), onde nosso exemplo mais próximo são os Estados Unidos da América, em que as decisões da Corte Suprema são acatadas como regra por todo o sistema judiciário e pela administração pública.

Como ressaltado pelo Ministro Carlos Velloso, "no sistema judicial norte-americano, que garante aos indivíduos, de modo amplo, a tutela jurisdicional, todos os Tribunais estão vinculados às decisões da Suprema Corte, nos casos em iguais estados de fato em que a decisão da Suprema Corte foi tomada. Isso, sem dúvida, proporciona segurança jurídica". ${ }^{13}$

A EC n. 45/04 não adotou o clássico stare decisis, nem tampouco transformou nosso sistema de civil law em common law, porém permitiu ao Supremo Tribunal Federal de ofício ou por provocação, mediante decisão de dois terços dos seus membros, após reiteradas decisões sobre matéria constitucional, aprovar súmula que, a partir de sua publicação na imprensa oficial, terá efeito vinculante em relação aos demais órgãos do Poder Judiciário e à administração pública direta e indireta, nas esferas federal, estadual e municipal, bem como proceder à sua revisão ou cancelamento, na forma estabelecida em lei, porém, desde logo, prevendo os requisitos mínimos para a imediata aplicabilidade.

4. Súmulas Vinculantes e Lei n. 11.417, de 19 de dezembro de 2006

A Lei n. 11.417/2006 trouxe algumas novidades em relação ao textobase da Constituição Federal, em especial ao estabelecer dois mecanismos geradores da edição, revisão e cancelamento de enunciados de súmulas vinculantes pelo STF: direto e incidental. ${ }^{14}$

O procedimento direto, nos termos do art. 103-A da Constituição Federal e da Lei n. 11.417/06, cuja vacatio legis foi de 3 meses, exige os seguintes requisitos e procedimento, sem prejuízo da disciplina subsidiária do regimento interno do Supremo Tribunal Federal.

Como órgão competente e exercente de jurisdição constitucional somente o Supremo Tribunal Federal poderá editar súmulas vinculantes; tendo por objeto a validade, a interpretação e a eficácia de normas determinadas.

As súmulas vinculantes poderão ser editadas de ofício ou por provocação de qualquer dos colegitimados para o ajuizamento de ações diretas de inconstitucionalidade que possuem legitimação constitucional (CF, art. 103, I a IX).

13 VELloso, Carlos Mário da Silva. Do poder judiciário: como torná-lo mais ágil e dinâmico - efeito vinculante em outros temas. Revista dos Tribunais, a. 6, n. 25, out./dez. 1998. p. 10.

14 Apesar de sua autoaplicabilidade, não houve a edição de súmula vinculante até a publicação da Lei n. 11.417, de 19 de dezembro de 2006, que disciplinou a edição, a revisão e o cancelamento dos enunciados das súmulas pelo Supremo Tribunal Federal. 
A Lei n. 11.417/06 ampliou a colegitimação para a propositura de edição, revisão ou cancelamento de enunciado de súmula vinculante, estendendo essa faculdade ao Defensor Público da União, aos Tribunais Superiores, aos Tribunais de Justiça de Estados ou do Distrito Federal e Territórios, aos Tribunais Regionais Federais, aos Tribunais Regionais do Trabalho, aos Tribunais Regionais Eleitorais e aos Tribunais Militares (legitimação legal).

A controvérsia atual entre órgãos judiciários ou entre esses e a administração pública que acarrete grave insegurança jurídica é requisito essencial para edição das súmulas vinculantes, deixando clara uma das finalidades dessa nova previsão constitucional, qual seja, a garantia da segurança jurídica, ao exigir a necessária discussão sobre os múltiplos argumentos jurídicos, antes de o Supremo Tribunal Federal editar uma súmula, pois, como salientado por Sálvio de Figueiredo Teixeira, "as súmulas vinculantes serão elaboradas com base na maturidade do trabalho jurisprudencial, fruto de lenta e prolongada atividade técnica dos juízes, de muitas e longas discussões, da observação atenta de casos repetidos". ${ }^{15}$

A EC n. 45/04, ao exigir também como requisito essencial a "relevante multiplicação de processos sobre questão idêntica", expôs a segunda importante finalidade das súmulas vinculantes, a preservação do princípio da igualdade, ou seja, a necessidade de uma mesma interpretação jurídica para uma questão idêntica que se repete em diversos processos, além de procurar efetivar o princípio da celeridade processual, consagrado no art. $5^{\circ}$, LXXVIII, e impedir a eternização de conflitos cujo posicionamento jurídico o STF já definiu.

O procedimento o contará com a participação do Procurador-Geral da República, e permite o ingresso do Amicus Curiae, nos termos do $\S 2^{\circ}$ do art. $3^{\circ}$ da Lei n. 11.417/06; exigindo, ainda, quorum qualificado de votação, pois a edição, revisão ou cancelamento de enunciados de súmulas vinculantes exige a maioria de $2 / 3$ dos membros do Supremo Tribunal Federal, em sessão plenária.

Porém, a grande novidade desse instrumento, foi a previsão de efeitos vinculantes com eficácia imediata, o que ampliou, enormemente, a força da Jurisdição Constitucional exercida pelo Supremo Tribunal Federal; juntamente com a possibilidade de manipulação dos efeitos gerados pelas súmulas vinculantes, ou seja, o art. $4^{\circ}$ da Lei n. 11.417/06 admitiu a modulação ou limitação temporal de efeitos na edição das súmulas vinculantes, estabelecendo que, por decisão de $2 / 3$ de seus membros, o Supremo Tribunal Federal poderá restringir os efeitos vinculantes ou decidir que só tenha eficácia a partir de outro momento, tendo em vista razões de segurança jurídica ou de excepcional interesse público.

15 TEIXEIRA, Sálvio de Figueiredo. Súmula vinculante e reforma do Judiciário. Correio Braziliense, Caderno Direito e Justiça, 9 fev. 1998. p. 3. 
O segundo mecanismo de edição, revisão ou cancelamento de enunciados de súmulas vinculantes - procedimento incidental -, criado especificamente pela Lei n. 11.417/06, difere do procedimento direto no tocante à legitimidade e à existência de caso específico em julgamento no STF, para que possa ser iniciado.

Dessa forma, o procedimento incidental para a edição, revisão ou cancelamento de enunciado de súmula vinculante exige os seguintes requisitos: (1) requisitos idênticos ao procedimento direto: objeto (validade, interpretação e eficácia de normas determinadas), controvérsia atual entre órgãos judiciários ou entre esses e a administração pública que acarrete grave insegurança jurídica e relevante multiplicação de processos sobre questão idêntica; (2) requisitos específicos: legitimidade e propositura no curso de processo. Assim, o Município poderá propor, incidentalmente ao curso de processo em que seja parte, a edição, a revisão ou o cancelamento de enunciado de súmula vinculante.

Ressalte-se que, tanto no procedimento direto, quanto no procedimento incidental, não haverá suspensão de processos que tenham por objeto a matéria discutida no Plenário do Supremo Tribunal Federal.

\section{Finalidades das Súmulas Vinculantes}

As exigências de controvérsia entre órgãos judiciários ou entre esses e a administração pública que acarrete grave insegurança jurídica (proteção ao princípio da segurança jurídica) e de relevante multiplicação de processos sobre questão idêntica (proteção aos princípios da igualdade e celeridade) demonstram que a correta edição e utilização das súmulas vinculantes pelo Supremo Tribunal Federal ${ }^{16}$ possibilitará a drástica redução do número de processos ${ }^{17}$ e a célere pacificação e solução uniforme de complexos litígios, que envolvam toda a coletividade e coloquem em confronto diferentes órgãos do Judiciário ou este com a administração pública. ${ }^{18}$

Além disso, assegurará direitos idênticos a todos, mesmo àqueles que não tenham ingressado no Poder Judiciário, mas, eventualmente, pudessem ser lesados pela administração, em virtude de seus efeitos vinculantes não só ao Poder Judiciário, mas também a todos os órgãos da administração pública direta e indireta.

16 Alertando para eventuais perigos na adoção desse mecanismo: VIANNA, Luiz Wernneck; CARVALHO, Maria Alice Rezende de; MELO, Manuel Palácios Cunha; BURGOS, Marcelo Baumann. Corpo e alma da magistratura brasileira. 2. ed. Porto Alegre: Revan, 1998. p. 37.

17 FRIEDE, Reis. Das reformas constitucionais. Revista dos Tribunais, São Paulo, a. 6, n. 25, p. 74-75, out./ dez. 1998. Nesse mesmo sentido: STRECK, Lenio Luiz. Súmulas no direito brasileiro: eficácia, poder e função. 2. ed. Porto Alegre: Livraria do Advogado, 1998. p. 143.

18 Em defesa das súmulas vinculantes: RAMOS, Saulo. Efeito vinculante das decisões dos tribunais superiores. Revista Brasileira de Ciências Criminais, n. 13, p. 148. 
O Supremo Tribunal Federal, reforçando as finalidades de proteção ao princípio da segurança jurídica e proteção aos princípios da igualdade e celeridade desse novo instituto, dotou as súmulas vinculantes de caráter impeditivo de recurso, permitindo, portanto, que os Tribunais ou Turmas recursais recorridos possam realizar e, eventualmente, negar a admissibilidade dos recursos extraordinários e dos agravos de instrumento contrários ao objeto da súmula.

Porém, a adoção de súmulas vinculantes não é unânime na doutrina nacional, gerando grandes controvérsias e posições antagônicas.

Maria Tereza Sadek expõe de forma clara as posições antagônicas, constatando que "a súmula vinculante (stare decisis) é vista por seus defensores como indispensável para garantir a segurança jurídica e evitar a multiplicação, considerada desnecessária, de processos nas várias instâncias. Tal providência seria capaz de obrigar os juízes de primeira instância a cumprir as decisões dos tribunais superiores, mesmo que discordassem delas, e impediria que grande parte dos processos tivesse continuidade, desafogando o Judiciário de processos repetidos. Seus oponentes, por seu lado, julgam que a adoção da súmula vinculante engessaria o Judiciário, impedindo a inovação e transformando os julgamentos de primeiro grau em meras cópias de decisões já tomadas. Dentre os que contestam tal expediente, há os que aceitam a súmula impeditiva de recurso, um sistema em que o juiz não fica obrigado a seguir o entendimento dos tribunais superiores do STF, mas permite que a instância superior não examine o recurso que contrarie a sua posição". ${ }^{19}$

A doutrina contrária às súmulas vinculantes afirma que haverá verdadeiro engessamento de todo o Poder Judiciário e consequente paralisia na evolução do Direito, ${ }^{20}$ além da possibilidade de maior totalitarismo do órgão de cúpula judicial, como alegado pelo professor Eros Grau, posteriormente Ministro do Supremo Tribunal Federal, hoje aposentado, ao se posicionar contra os efeitos vinculantes e afirmar que "nenhuma razão ou pretexto se presta a justificar essa manifestação de totalitarismo, que também nenhuma lógica pode sustentar, e que, afinal, há de agravar ainda mais a crise do direito oficial, em nada contribuindo à restauração da sua eficácia". ${ }^{21}$

19 SADEK, Maria Tereza. Judiciário: mudanças e reformas. Estudos avançados, v. 18, n. 51, p. 91-92, maio/ ago. 2004.

20 Nesse sentido: SILVA, José de Anchieta da. A súmula de efeito vinculante amplo no direito brasileiro: um problema e não uma solução. Belo Horizonte: Del Rey, 1998. p. 28; FRANCO, Nelson Pinheiro. Aspectos do Poder Judiciário. Revista da Escola Paulista de Magistratura, a. 1, n. 3, p. 185, maio/out. 1997; SILVA, José de Anchieta da. A súmula de efeito vinculante amplo no direito brasileiro: um problema e não uma solução. Belo Horizonte: Del Rey, 1998.

21 GRAU, Eros Roberto. Sobre a produção legislativa e a normativa do direito oficial: o chamado 'efeito vinculante'. Revista da Escola Paulista de Magistratura, ano 1, n. 3, p. 78, maio/out. 1997. 
Não concordamos com esse posicionamento, nem tampouco nos parece que a edição de súmulas vinculantes poderá acarretar o engessamento e consequente paralisia na evolução e interpretação do Direito, ${ }^{22}$ desde que o Supremo Tribunal Federal edite "Sumulas Vinculantes" como "extratos dos precedentes anteriormente julgados", abstendo-se do exercício da pura edição de "Súmulas abstratas", tal qual textos legislativos, pois estaria invadindo a seara do Poder Legislativo.

A própria história do stare decisis afasta essas alegações, pois, entre todos os tribunais, nenhum se notabilizou tanto pela defesa intransigente, polêmica, construtiva e evolutiva dos direitos fundamentais como a Suprema Corte americana, mesmo adotando o mecanismo de vinculação, não podendo, porém, ser acusada de imutabilidade interpretativa.

Com o passar dos anos, a defesa dos direitos fundamentais pela Corte Suprema seguiu a evolução da sociedade norte-americana, passando a colocar a pessoa humana em primeiro plano, mesmo em detrimento do direito de propriedade, inicialmente defendido de maneira tão ciosa no sistema da common law.

Relembre-se, nesse sentido, o famoso caso Dred Scott (Scott v. Sandford, 19 How. 393-1857), em que a Corte Suprema julgou inconstitucional a seção $8^{a}$ do Missouri Compromise Act, de 1850, que proibira a escravidão nos territórios, por entender sua contrariedade à $5^{\mathrm{a}}$ Emenda (due process of law $)^{23} \mathrm{e}$, mesmo após a abolição da escravatura, basta analisar o ativismo judicial da Corte de Warren, que encerrou com a segregação racial nos Estados Unidos, quando a Corte, em 17 maio de 1954, entendeu, revogando precedente de 1866, que a existência de separação nas escolas para os negros era incompatível com a $14^{\mathrm{a}}$ Emenda, que garante a igual proteção

22 Nesse mesmo sentido: MOREIRA NETO, Diogo de Figueiredo. Poder Judiciário e seu papel na reforma do estado: o controle jurisdicional dos atos administrativos e a súmula vinculante. Revista dos Tribunais, São Paulo, a. 7, n. 27, p. 31, abr./jun. 1999.

23 Cf. HALL, Kermit L. The Oxford guide to United States Supreme Courts decisions. New York: Oxford University Press, 1999. p. 277. 
das leis, e, portanto, a discriminação racial nas escolas públicas era flagrantemente inconstitucional, ${ }^{24}$ tendo, atuação memorável o Chief Justice Warren. ${ }^{25}$

O próprio Direito inglês alterou tradicional regra de imutabilidade em seus precedentes, consagrada pela Câmara dos Lordes em 1898, no caso London Tramways v. London County Council, e adotou, após 68 anos, nova orientação, que desobriga a Câmara dos Lordes à obrigatoriedade de seus precedentes (regra adotada em 26-7-1966, no Practice Statement of 1966, lido pelo Lord Gardiner, no Parlamento Inglês).

O fundamento da alteração foi a consciência de que uma rígida aderência aos precedentes pode levar a injustiças e também restringir indevidamente a adequada evolução do Direito. Observe-se, porém, que mesmo após a adoção do novo posicionamento, são excepcionais e raríssimos os casos em que a Câmara dos Lordes alterou os próprios precedentes, em prol da segurança jurídica. ${ }^{26}$

A EC n. 45/04 possibilitou ao Supremo Tribunal Federal, assim como à Corte Suprema Americana e à Câmara dos Lordes inglesa, a não vinculação ad eternum a seus próprios precedentes, podendo, a partir de novas provocações, reflexões e diversas decisões futuras, alterar a interpretação dada em matéria constitucional e, consequentemente, proceder à revisão ou cancelamento da súmula, o que impedirá qualquer forma de engessamento e paralisia na evolução do Direito, sem, contudo, desrespeitar os princípios da igualdade, segurança jurídica e celeridade processual. ${ }^{27}$

24 A Corte Suprema determinou a junção dos segregation cases Brown v. Board of Education of Topeka (347 U.S. 483 - 1954) e Bolling v. Sharpe (347 U. S. 497 - 1954). Em virtude da gravidade social da decisão, somente após um ano, ou seja, em 31 maio de 1955, a Corte determinou às autoridades escolares que concretizassem com toda deliberada pressa (with all deliberate speed) o fim da discriminação racial nas escolas, delegando aos juízes federais a fiscalização e efetividade de sua decisão. Note-se que a concretização de alteração social tão profunda na prática mostrou-se de dificuldade ímpar. Somente em 1964, a Corte Suprema determinou o fim do prazo para que as autoridades educacionais agissem com toda deliberada pressa (with all deliberate speed) e declarou inconstitucional a transformação de escolas públicas em privadas, com a única finalidade de mantença da segregação racial (Griffin v. County Board of Price Edward County (377 U.S. 218), 1964). Em 1969, a Suprema Corte ordenou que os distritos escolares, finalmente, encerrassem imediatamente o sistema de discriminação racial em todas as escolas públicas, decretando o início do sistema educacional unitário (Alexander v. Holmes County Board of Education (396 U.S. 19), 1969).

25 O Chief Justice Warren afirmou que: "atualmente, é duvidoso se possa esperar vença alguma criança na vida, caso se the negue a oportunidade de educar-se. Tal oportunidade quando o Estado tomou a seu cargo provê-la, constitui direito que deve ser acessível a todos, em igualdade de condições, ... apesar de poderem ser iguais os fatores tangíveis, a segregação de crianças nas escolas públicas apenas por motivo racial priva grupos minoritários de iguais oportunidades educacionais", para concluir que "separá-las de outras de idade e qualificações semelhantes devido apenas à sua raça gera sentimento de inferioridade quanto ao seu status na comunidade que pode contaminar seus corações e espíritos de modo irreparável".

26 Cf. CROSS, Rupert; HARRIS, J. W. Precedent in English law. Oxford: Clarendon Press, 1991. p. 102-108.

27 Conferir, nesse mesmo sentido: FRIEDE, Reis. Das reformas constitucionais. Revista dos Tribunais, a. 6, n. 25, p. 74-75, out./dez. 1998. 
6. Revisão e cancelamento das Súmulas Vinculantes e possibilidade de distinção nos casos concretos

Dessa forma, nos termos do $\S 2^{\circ}$, do art. 103-A, da Constituição Federal, regulamentado pela Lei n. 11.417/06, a revisão ou cancelamento de súmula poderá ser, igualmente, de ofício ou provocada por um dos colegitimados, tanto pelo procedimento direto, quanto pelo procedimento incidental.

Ressalte-se, ainda, que, reforçando a possibilidade de mutação e evolução interpretativa do Direito sumular, a Lei n. 11.417/06 estabeleceu que, revogada ou modificada a lei em que se fundou a edição de enunciado de súmula vinculante, o Supremo Tribunal Federal, de ofício ou por provocação, procederá à sua revisão ou cancelamento, conforme o caso.

Além disso, é importante ressaltar que competirá a cada um dos magistrados, ao analisar o caso concreto, a conclusão pela aplicação de determinada súmula ou não, ou mesmo a possibilidade de apontar novos pontos característicos que não se encontram analisados na Súmula, ou ainda, a necessidade de alteração da súmula em virtude da evolução do Direito, de maneira semelhante ao que ocorre no direito norte-americano, quando o juiz utiliza-se do mecanismo processual do distinguishing (distinção entre o caso concreto e o precedente judicial) para demonstrar que não é o caso de aplicação de determinado precedente na hipótese em julgamento.

A EC n. 45/04, corretamente, não previu, por exagerado e inútil, nenhum mecanismo que possa responsabilizar disciplinarmente o juiz pela não adoção das súmulas vinculantes. ${ }^{28}$ A proteção da validade das súmulas vinculantes editadas pelo Supremo Tribunal Federal será feita da mesma maneira como vem ocorrendo com os efeitos vinculantes nas ações diretas de inconstitucionalidade e nas ações declaratórias de constitucionalidade, por meio de reclamações.

Assim, do ato administrativo ou decisão judicial que contrariar a súmula aplicável ou que indevidamente a aplicar, caberá reclamação ao Supremo Tribunal

28 Lawrence Baum aponta que, apesar de existir esse mecanismo nos Estados Unidos, jamais a Corte Suprema utilizou-se da possibilidade de declarar um juiz culpado por desacato, embora quase fizesse isso num caso em 1969 (In re Herndon). O autor cita como exemplo o caso Hawkins v. Universidade da Flórida, em que, apesar de a Corte Suprema ter determinado, primeiramente (1954), que a Corte Suprema da Flórida reexaminasse a negativa de acesso do negro Hawkins à Faculdade de Direito da Universidade da Flórida, somente frequentada por brancos e, posteriormente (1956), que Hawkins tinha direito a pronta admissão, por uma série de manobras a Corte Estadual negou-se a executar a decisão, não tendo a Corte Suprema aplicado qualquer sanção aos juízes da mesma (BAUM, Lawrence. A suprema corte americana. Rio de Janeiro: Forense Universitária, 1987. p. 300-301). Poderíamos, ainda, citar outros exemplos históricos, como no caso dos índios da Geórgia, em que o Estado da Geórgia, apoiado pelo Presidente Jackson, apropriou-se das terras indígenas e desobedeceu à ordem da Corte de Marshall para restituí-las. 
Federal que, julgando-a procedente, anulará o ato administrativo ou cassará a decisão judicial reclamada, e determinará que outra seja proferida com ou sem a aplicação da súmula, conforme o caso, sem prejuízo dos recursos cabíveis ou outros meios admissíveis de impugnação (art. $7^{\circ}$ da lei).

Em se tratando de descumprimento administrativo de enunciado de súmula vinculante, por omissão ou ato da administração, a reclamação será cabível após o esgotamento das vias administrativas. Nesses casos, a própria Lei n. 11.417/06 previu a necessidade de explicitação das razões de aplicabilidade ou inaplicabilidade do enunciado da súmula vinculante pela autoridade administrativa prolatora da decisão impugnada, se não a reconsiderar; antes de encaminhar o recurso à autoridade superior; competindo, igualmente, à autoridade administrativa competente para decidir o recurso explicitar as razões da aplicabilidade ou inaplicabilidade da súmula.

Observe-se, porém, que para não tornar inócuos os efeitos vinculantes das súmulas do STF, a Lei n. 11.417/06 alterou a legislação sobre processo administrativo no âmbito da Administração Pública Federal (Lei n. 9.784/99), estabelecendo que, acolhida pelo Supremo Tribunal Federal a reclamação fundada em violação de enunciado da súmula vinculante, será dada ciência à autoridade prolatora da decisão e ao órgão competente para o julgamento do recurso, que deverão adequar as futuras decisões administrativas, em casos semelhantes, sob pena de responsabilização de pessoas nas esferas cível, administrativa e penal.

Por vislumbrar ofensa à Súmula Vinculante $13,{ }^{29}$ por exemplo, o STF suspendeu a nomeação de irmão de Governador de Estado para o cargo de Conselheiro do Tribunal de Contas. ${ }^{30}$ Igualmente, a Corte, em medida cautelar em Reclamação 8.225/SC, concedida pelo Ministro Celso de Mello, garantiu o efetivo cumprimento da Súmula Vinculante $14,{ }^{31}$ em defesa do princípio constitucional da ampla defesa.

29 Súmula Anti-nepotismo: “A nomeação de cônjuge, companheiro ou parente em linha reta, colateral ou por afinidade, até o terceiro grau, inclusive, da autoridade nomeante ou de servidor da mesma pessoa jurídica investido em cargo de direção, chefia ou assessoramento, para o exercício de cargo em comissão ou de confiança ou, ainda, de função gratificada na administração pública direta e indireta em qualquer dos Poderes da União, dos Estados, do Distrito Federal e dos Municípios, compreendido o ajuste mediante designações recíprocas, viola a Constituição Federal".

30 STF - Pleno - Rcl. 6702 AgR-MC/PR, Rel. Min. Ricardo Lewandowski, 4-3-2009, Informativo STF n. 537.

31 "É direito do defensor, no interesse do representado, ter acesso amplo aos elementos de prova que, já documentados em procedimento investigatório realizado por órgão com competência de polícia judiciária, digam respeito ao exercício do direito de defesa". 


\section{As Súmulas Vinculantes e o ativismo judicial}

O ativismo judicial, expressão utilizada pela primeira vez em 1947 por Arthur Schlesinger Jr., em artigo sobre a Corte Suprema dos EUA, no Direito brasileiro tornou-se, portanto, tema de extrema relevância, não só quanto à sua possibilidade, mais, principalmente, em relação aos seus limites, pois há muita polêmica sobre a prática do ativismo judicial, inclusive no tocante à sua conceituação.

Ativismo judicial seria "uma filosofia quanto à decisão judicial mediante a qual os juízes permitem que suas decisões sejam guiadas por suas opiniões pessoais sobre políticas públicas, entre outros fatores" (cf. a respeito, Black's Law Dictionary), sendo apontado por alguns doutrinadores norte-americanos como uma prática, que por vezes indica a ignorância de precedentes, possibilitando violações à Constituição; ou, seria um método de interpretação constitucional, no exercício de sua função jurisdicional, que possibilita, por parte do Poder Judiciário, a necessária colmatação das lacunas constitucionais geradas pela omissão total ou parcial dos outros Poderes, ou ainda, pelo retardamento da edição de normas que possibilitem a plena efetividade do texto constitucional?

Teríamos com o ativismo judicial, clara afronta à Separação de Poderes, com direta usurpação das funções da legislatura ou da autoridade administrativa, como por diversas vezes apontou o Juiz Antonin Scalia, da Suprema Corte dos Estados Unidos, para desqualificar essa prática (cf. voto vencido no caso Romer v. Evans, 1996); ou, verdadeira necessidade constitucional permitida pelo sistema de freios e contrapesos em face da finalidade maior de garantir a plena supremacia e efetividade das normas constitucionais?

Não há dúvidas de que a eficácia máxima das normas constitucionais exige a concretização mais ampla possível de seus valores e de seus princípios, porém, em caso de inércia dos poderes políticos, devemos autorizar a atuação subjetiva do Poder Judiciário (Luis Roberto Barroso), mesmo que isso transforme o Supremo Tribunal Federal em um super-legislador, pois imune de qualquer controle, que não seja a própria auto-contenção (judicial restraint), ou, devemos restringi-lo, para que não se configure flagrante desrespeito aos limites normativos substanciais da função jurisdicional, usurpando, inclusive, função legiferante (Elival da Silva Ramos)?

A história do ativismo judicial norte-americano mostra, em face de seu alto grau de subjetivismo, momentos diversos na defesa dos Direitos Fundamentais. Há, claramente, decisões ativistas alinhadas com o pensamento progressista, enquanto outras, com o mais radical conservadorismo.

Aponta-se, como a primeira decisão considerada como ativista, embora inexistisse a terminologia à época, o anteriormente citado caso Dred Scott, de 1857 , 
quando julgando uma lei que libertava automaticamente os escravos que ingressassem num território onde a escravidão tivesse sido anteriormente abolida, a Suprema Corte declarou-a inconstitucional, por ferir o direito de propriedade, protegido pela cláusula do due process of law. Igualmente, a mesma cláusula do devido processo legal foi invocada na decisão Lochner v. New York, de 1905, permitindo que a Corte invalidasse direito social consagrado pela legislação, que passará a limitar a jornada de trabalho dos padeiros a dez horas diárias; o argumento foi de que a lei privava os cidadãos de sua liberdade de contratar.

Por outro lado, o ativismo judicial foi de imperiosa importância na questão racial norte-americana durante a Corte Warren, especialmente a partir da decisão, também já referida, de Brown v. Board of Education, de 1954, em que a Corte Suprema, derrubando seu próprio precedente (Plessy v. Ferguson, de 1896), decidiu ser inconstitucional lei que adotava a doutrina "iguais, mas separados", permitindo instalações públicas separadas para negros e brancos, desde que - teoricamente fossem de igual qualidade; e, com essa postura ativa deu início ao fim da segregação racial nos Estados Unidos da América.

Outros Direitos Fundamentais foram consagrados e efetivados com a possibilidade de maior amplitude interpretativa por parte do Judiciário, como se vê em clássicas decisões ativistas da Suprema Corte Americana, tais como, o reconhecimento do direito constitucional à privacidade (Griswold v. Connecticut, de 1965), a necessidade de que toda pessoa presa em flagrante ser alertada sobre seus direitos constitucionais (Miranda v. Arizona, 1966), e o mais controvertido de todos, o reconhecimento do direito constitucional ao aborto, como projeção do direito à privacidade (caso Roe v. Wade, 1973).

Não são poucos os doutrinadores que, apontam enorme perigo à Democracia e à vontade popular, na utilização do ativismo judicial, pois como salientado por Ronald Dworkin, “o ativismo é uma forma virulenta de pragmatismo jurídico. Um juiz ativista ignoraria o texto da Constituição, a história de sua promulgação, as decisões anteriores da Suprema Corte que buscaram interpretá-la e as duradouras tradições de nossa cultura política ativista ignoraria tudo isso para impor a outros poderes do Estado o seu próprio ponto de vista sobre o que a justiça exige." ${ }^{32}$

Por outro lado, não se pode ignorar a advertência feita pelo Ministro Celso de Mello, ao recordar que as "práticas de ativismo judicial, embora moderadamente desempenhadas por esta Corte em momentos excepcionais, tornamse uma necessidade institucional, quando os órgãos do Poder Público se omitem ou

32 DWORKIN, Ronald. O império do direito. São Paulo: Martins Fontes, 2007. p. 451. 
retardam, excessivamente, o cumprimento de obrigações a que estão sujeitos por expressa determinação do próprio estatuto constitucional, ainda mais se se tiver presente que o Poder Judiciário, tratando-se de comportamentos estatais ofensivos à Constituição, não pode se reduzir a uma posição de pura passividade." 33

\section{Conclusão}

O Estado Constitucional conciliando de forma harmônica e fortalecendo aos noções de Estado de Direito e Estado Democrático, introduziu fortemente no constitucionalismo efetivas garantias de legitimação e limitação do poder; e, se, realmente, como afirmou o professor Jean Marcou, da Universidade de Grenoble, " $o$ século XX é o século dos tribunais constitucionais”, o século XXI deve ser o século do equilíbrio entre a Jurisdição Constitucional e as Instituições legislativas.

No Brasil, esse necessário equilíbrio entre a Jurisdição Constitucional e as Instituições Legislativas tornou-se mais premente com a possibilidade de edição de Súmulas Vinculantes por parte do Supremo Tribunal Federal, não só em matéria de vigência e eficácia da legislação (tradicional função de legislador negativo dos Tribunais Constitucionais), mas também em função dessa possibilidade ser direcionada à interpretação da legislação face ao texto constitucional, permitindo uma verdadeira atuação de legislador positivo, com grandes reflexos na possibilidade de ampliação do ativismo judicial.

O bom senso entre a "passividade judicial" e o "pragmatismo jurídico", entre o "respeito à tradicional formulação das regras de freios e contrapesos da Separação de Poderes" e "a necessidade de garantir às normas constitucionais à máxima efetividade" deve guiar o Poder Judiciário, e, em especial, o Supremo Tribunal Federal na aplicação do ativismo judicial, com a apresentação de metodologia interpretativa clara e fundamentada, de maneira a balizar o excessivo subjetivismo, permitindo a análise crítica da opção tomada, com o desenvolvimento de técnicas de auto-contenção judicial, principalmente, afastando sua aplicação em questões estritamente políticas, e, basicamente, com a utilização minimalista desse método decisório, ou seja, somente interferindo excepcionalmente de forma ativista, mediante a gravidade de casos concretos colocados e em defesa da supremacia dos Direitos Fundamentais.

São Paulo, maio de 2012.

33 Discurso do Ministro Celso de Mello na posse do min. Gilmar Mendes na presidência do STF, 23.4.2008. 


\section{Referências}

CAETANO, Marcello. Direito constitucional. 2. ed. Rio de Janeiro: Forense, 1987. v. 1.

CANOTILHO, J. J. Gomes. Direito constitucional e teoria da Constituição. Coimbra: Almedina, 2003.

; MOREIRA, Vital. Fundamentos da Constituição. Coimbra: Coimbra Editora, 1991.

CROSS, Rupert; HARRIS, J. W. Precedent in English law. Oxford: Clarendon Press, 1991.

DUGUIT, Leon. Fundamentos do Direito. São Paulo: Íconce.

DUVERGER, Maurice. Os partidos politicos. Rio de Janeiro: Zahar, 1970.

DWORKIN, Ronald. O império do direito. São Paulo: Martins Fontes, 2007.

FRANCO, Nelson Pinheiro. Aspectos do poder judiciário. Revista da Escola Paulista de Magistratura, a. 1, n. 3, p. 185, maio/out. 1997.

FRIEDE, Reis. Das reformas constitucionais. Revista dos Tribunais, a. 6, n. 25, p. 74-75, out./ dez. 1998.

GRAU, Eros Roberto. Sobre a produção legislativa e a normativa do direito oficial: o chamado 'efeito vinculante'. Revista da Escola Paulista de Magistratura, a. 1, n. 3, p. 78, maio/out. 1997.

HALL, Kermit L. The Oxford guide to United States Supreme Courts decisions. New York: Oxford University Press, 1999.

MIRANDA, Jorge. Manual de direito constitucional. 4. ed. Coimbra: Coimbra Editora, 1990. t. 1 e 3 .

. Textos históricos do direito constitucional. 2. ed. Lisboa: Imprensa Nacional, 1990.

MIRANDA, Pontes. Comentários à Constituição de 1946, v. I.

MORAES, Alexandre de. Direito constitucional. 26. ed. São Paulo: Atlas, 2010.

. Constituição interpretada e legislação constitucional. 8. ed. São Paulo: Atlas, 2007.

. Jurisdição constitucional e tribunais constitucionais. 2. ed. São Paulo: Atlas, 2002.

. Presidencialismo. 2. ed. São Paulo: Atlas, 2004.

MOREIRA NETO, Diogo de Figueiredo. Poder Judiciário e seu papel na reforma do estado: o controle jurisdicional dos atos administrativos e a súmula vinculante. Revista dos Tribunais, São Paulo, a. 7, n. 27, p. 31, abr./jun. 1999.

RAMOS, Saulo. Efeito vinculante das decisões dos tribunais superiores. Revista Brasileira de Ciências Criminais, n. 13. 
SADEK, Maria Tereza. Judiciário: mudanças e reformas. USP - Estudos avançados, v. 18, n. 51, p. 91-92, maio/ago. 2004.

SILVA, José de Anchieta da. A súmula de efeito vinculante amplo no direito brasileiro: um problema e não uma solução. Belo Horizonte: Del Rey, 1998.

STRECK, Lenio Luiz. Súmulas no direito brasileiro: eficácia, poder e função. 2. ed. Porto Alegre: Livraria do Advogado, 1998.

TEIXEIRA, Sálvio de Figueiredo. Súmula vinculante e reforma do Judiciário. Correio Braziliense, Caderno Direito e Justiça, 9 fev. 1998, p. 3.

VELLOSO, Carlos Mário da Silva. Do poder judiciário: como torná-lo mais ágil e dinâmico efeito vinculante em outros temas. Revista dos Tribunais, São Paulo, a. 6, n. 25, out./dez. 1998. VERDÚ, Pablo Lucas. A luta pelo estado de direito. Trad. Agassiz Almeida Filho. Rio de Janeiro: Forense, 2007.

VERGOTTINI, Giuseppe de. Diritto costituzionale comparato. Pádua: Cedam, 1981.

VIANNA, Luiz Wernneck; CARVALHO, Maria Alice Rezende de; MELO, Manuel Palácios Cunha; BURGOS, Marcelo Baumann. Corpo e alma da magistratura brasileira. 2. ed. Porto Alegre: Revan, 1998. 